\title{
Vasopressin Antagonists: Role in the Management of Hyponatremia
}

\author{
Karen E. Yeates A. Ross Morton \\ Department of Medicine, Queen's University, Kingston, Canada
}

\section{Key Words}

Hyponatremia • Vasopressin • Salt-water balance · Sodium • Syndrome of inappropriate secretion of antidiuretic hormone $\cdot$ Antidiuretic hormone $\cdot$ Homeostasis

\begin{abstract}
Hyponatremia is a common electrolyte disorder associated with potentially serious or life-threatening consequences. Serum osmolality and sodium concentration $\left[\mathrm{Na}^{+}\right]$are regulated by thirst, the hormone arginine vasopressin (AVP), and renal water and sodium handling. Hyponatremia is frequently caused by dysregulation of AVP, which accompanies disorders of water retention, such as congestive heart failure (CHF) and the syndrome of inappropriate secretion of antidiuretic hormone (SIADH). Clinical trials with AVP receptor antagonists have confirmed the important role of AVP in the pathophysiology of hyponatremia and suggest these agents are efficacious in treating hyponatremia associated with $\mathrm{SIADH}$, cirrhosis, and CHF. Acting directly at AVP receptors in the renal tubules, these agents promote aquaresis - the electrolyte-sparing excretion of free water - in patients with hyponatremia. In clinical trials, AVP receptor antagonists have been shown to increase the serum $\left[\mathrm{Na}^{+}\right]$and urine output while decreasing urine osmolality.
\end{abstract}

Copyright $\odot 2006$ S. Karger AG, Basel

\section{KARGER}

Fax +41613061234

E-Mail karger@karger.ch

www.karger.com
(C) 2006 S. Karger AG, Basel

0250-8095/06/0264-0348\$23.50/0

Accessible online at:

www.karger.com/ajn

\section{Introduction}

Hyponatremia, defined as a serum sodium concentration $\left(\left[\mathrm{Na}^{+}\right]\right)$less than $136 \mathrm{mEq} / \mathrm{l}$, is the most common electrolyte disorder in hospitalized patients [1]. The disorder may be evident on admission as a complication of underlying disease or it can occur during hospitalization. The reported prevalence of hyponatremia varies depending on the definition of hyponatremia used and the population studied. For example, the prevalence of hyponatremia among hospitalized patients when the disorder is defined as a serum $\left[\mathrm{Na}^{+}\right]<134 \mathrm{mEq} / 1$ is $15 \%$ and ranges from 3 to $15 \%$ when the disorder is defined as a serum $\left[\mathrm{Na}^{+}\right]<130 \mathrm{mEq} / 1[2-4]$. The prevalence of hyponatremia also increases with age [5]. The probability of hyponatremia developing during hospitalization is more than twice as high among people aged 51-60 years than among those aged 30 years and increases about 5 -fold in people older than 70 years [5].

Hyponatremia can be a contributing factor to morbidity and death in hospitalized patients. A retrospective analysis of 78 hospitalized patients with a serum $\left[\mathrm{Na}^{+}\right]$ $\leq 128 \mathrm{mEq} / \mathrm{l}$ showed that the mortality among these patients was $27 \%$ [6]. Furthermore, in a prospective study with 1,088 postoperative patients, hyponatremia (serum $\left.\left[\mathrm{Na}^{+}\right]<130 \mathrm{mEq} / \mathrm{l}\right)$ developed in $4.4 \%$. Among these pa- 
tients, the mortality was $4.2 \%$, compared with $0.2 \%$ among patients who did not have hyponatremia or did not undergo serum $\left[\mathrm{Na}^{+}\right]$measurements. In a study of 4,532 patients aged 65 years or older, the risk of death among patients with hyponatremia (serum $\left[\mathrm{Na}^{+}\right]$ $<130 \mathrm{mEq} / \mathrm{l})$ at admission was twice as high as that among patients in the same age group who did not have hyponatremia at admission (16 vs. $8 \%$, respectively) [7].

Most significant sequelae of hyponatremia result from its effects on the central nervous system. Hyponatremia carries a significant risk of permanent brain damage or death from encephalopathy. The magnitude and duration of hyponatremia were once believed to predict the risk of hyponatremic encephalopathy, but age, sex, and hormonal status are now believed to be the more prominent risk factors. Although the incidence of hyponatremia is similar among men and women, brain damage occurs predominantly in younger menstruant women and in preadolescents of either sex [8]. Hypoxia impedes compensatory changes in the brain as it tries to adapt to hyponatremia and stimulates the antidiuretic hormone arginine vasopressin (AVP). Hypoxia can also lead to permanent brain damage and death. The risk of respiratory arrest in patients with symptomatic hyponatremia is much greater than that in patients who receive inappropriate treatment [8].

Serum sodium is the principal solute governing serum osmolality, which is determined by the total solute concentration in a fluid compartment [9]. The balance between sodium and water is maintained as needed by increased water intake (thirst) during periods of hyperosmolality or by increased renal free water clearance (FWC) during periods of hypoosmolality. The major regulatory factor in the maintenance of total body volume is AVP. Both thirst and AVP release are stimulated by hypertonicity. Tonicity describes the collective ability of all solutes in a compartment to create an osmotic gradient for net water movement between compartments. Tonicity will therefore increase when the extracellular $\left[\mathrm{Na}^{+}\right]$rises. Impaired regulation of AVP leads to a disruption in water balance, resulting in hyponatremia.

Current therapeutic approaches to hyponatremia produce variable and often disappointing results because they do not address the underlying etiology or effects of AVP dysregulation. AVP receptor antagonists, a new class of drugs for the treatment of hyponatremia, act on AVP receptors in the renal tubules to promote aquaresis - the electrolyte-sparing excretion of water - and subsequently increase the serum $\left[\mathrm{Na}^{+}\right]$.

Vasopressin Antagonists for Treatment of Hyponatremia

\section{AVP in Normal and Dysregulated Water Handling}

\section{AVP Release: Osmotic and Nonosmotic Stimuli}

AVP is a 9-amino acid peptide hormone that is synthesized by neuronal cell bodies in the hypothalamus. AVPcarrying neurosecretory granules travel down the supraoptic hypophyseal tract and are stored in the posterior pituitary $[10,11]$. In response to the appropriate trigger, their release occurs quantally by exocytosis from the granules [12].

The control of AVP release is governed by both osmotic and nonosmotic stimuli, with changes in osmolality serving as the primary stimulus for hormone release. AVP release is controlled through an exquisitely sensitive system that detects extracellular fluid (ECF) osmolality. Two unique groups of osmoreceptors in the hypothalamus detect ECF osmolality. One group of relatively highthreshold receptors stimulates thirst when plasma osmolality reaches approximately $288-294 \mathrm{mosm} / \mathrm{kg}[13,14]$. The other group of osmoreceptors signals water reabsorption at the kidney by triggering AVP release if the ECF exceeds the osmolality set-point, which is usually $280 \mathrm{mosm} / \mathrm{kg}$ [9]. The relationship between AVP release and increasing osmolality is linear and steep beyond the set-point [13].

The exact threshold for AVP release declines with age and during pregnancy $[15,16]$. The slope of the osmolality-AVP response is also modified in relation to increases and decreases of blood volume and pressure. In the healthy individual, the renal response to AVP is also linear, and a decrease in urine flow and accompanying increase in urine osmolality will follow in proportion to the systemic AVP level [14].

In patients with inappropriate AVP regulation, the balance between osmolality and water reabsorption can be lost by dysregulation of the intensity or duration of AVP release. In some cases, the osmoreceptor set-point can be disturbed, resulting in the inappropriate release of AVP despite normal osmolality. In the syndrome of inappropriate antidiuretic hormone (SIADH), for example, the AVP level may be disproportionately elevated in relation to the tonicity of body fluids.

In contrast with the intricate control of water reabsorption directed by the osmoreceptor, nonosmotic AVP release is relatively insensitive. A decrease in the effective arterial volume of approximately $10 \%$ is necessary to trigger AVP release [9]. Unlike the direct linear relationship with osmolality, the relationship between volume depletion and AVP release is curvilinear. The release of AVP may also be stimulated by nausea, pain, and medications,

Am J Nephrol 2006;26:348-355 
Table 1. Causes and characteristics of hyponatremia [18]

\begin{tabular}{|c|c|c|c|}
\hline & \multicolumn{3}{|l|}{ Volume of ECF } \\
\hline & hypovolemia & euvolemia & hypervolemia \\
\hline Causes & $\begin{array}{l}\text { Diarrhea; vomiting; } \\
\text { excessive sweating; } \\
\text { poor water intake; diuretic use }\end{array}$ & $\begin{array}{l}\text { SIADH; hypothyroidism; } \\
\text { adrenal insufficiency }\end{array}$ & $\begin{array}{l}\text { CHF; cirrhotic liver disease; } \\
\text { nephrotic syndrome }\end{array}$ \\
\hline Serum osmolality & Low & Low & Low \\
\hline Urine osmolality ${ }^{\mathrm{a}}$, mosm $/ \mathrm{kg}$ & $>500$ & $>100$ & $>100$ \\
\hline Urine volume & Usually decreased & Varies with intake & Usually decreased \\
\hline Urine sodium, mEq/l & $<20^{\mathrm{b}}$ & $>40$ & $<20^{\mathrm{b}}$ \\
\hline Response to $0.9 \%$ saline infusion & $\begin{array}{l}\text { Clinical and biochemical } \\
\text { improvement }\end{array}$ & $\begin{array}{l}\text { No change or worsening of } \\
\text { hyponatremia }\end{array}$ & $\begin{array}{l}\text { Little change in hyponatremia; } \\
\text { worsening of edema }\end{array}$ \\
\hline
\end{tabular}

For simplicity, conditions such as cerebral salt wasting and reset osmostat have been omitted.

a Values $<100 \mathrm{mosm} / \mathrm{kg}$ represent a normal pituitary and renal response to hyponatremia, as would be expected in psychogenic polydipsia. The variability in urine osmolality results in a low sensitivity and specificity for causes of hyponatremia for which the urine osmolality is $>100 \mathrm{mosm} / \mathrm{kg}$.

${ }^{b}$ May be $>20 \mathrm{mEq} / \mathrm{l}$ in association with diuretic use.

such as chlorpropamide, carbamazepine, clofibrate, vincristine, and cyclophosphamide [13].

\section{Classification of Hyponatremia}

\section{Volume Status}

In patients with hyponatremia, the disorder may be hypovolemic, euvolemic, or hypervolemic (table 1), depending on their extracellular volume status, which is determined from the medical history, daily fluid input and output measurements, and physical examination [17].

Hypovolemic hyponatremia begins when volume is decreased by conditions such as diarrhea, vomiting, diuretic use, or excessive sweating, all of which lead to the loss of both sodium and water. When the extracellular loss is reversed with hypotonic fluids, such as oral free water, the net sodium loss is disproportionally greater than water loss, which can lead to hypovolemic hyponatremia [18]. Furthermore, AVP secretion is increased as part of the compensatory response to defend against volume contraction, which increases water reabsorption and further decreases ECF osmolality.

Hypervolemic states such as congestive heart failure (CHF), cirrhosis, and nephrotic syndrome are associated with an increased ECF volume and dilution of electrolytes [19]. In these volume-expanded states, the effective intravascular circulating volume is diminished, resulting in poor renal perfusion. The kidney will retain sodium and water avidly even as the total body water and sodium are increased. In these edematous states, hyponatremia occurs when total body water increases more than sodium. Much of the increased body water is due to an elevated AVP level [18].

Euvolemic hyponatremia occurs in patients with normal or near normal ECF volume. SIADH represents the most common form of euvolemic hyponatremia among hospitalized patients. Patients with SIADH usually do not demonstrate any clinical signs of edema, because only a portion of the retained fluid is distributed in the ECF [20]. In SIADH, AVP levels are elevated and the kidneys retain free water, but sodium handling remains intact. The cardinal features of SIADH include (1) hypoosmolar hyponatremia, (2) continued renal excretion of sodium, (3) the absence of clinical evidence of volume depletion, (4) inappropriate urine osmolality (i.e., less than maximally dilute urine), and (5) normal renal and adrenal function [21].

It is often difficult to differentiate between subtle volume depletion and euvolemic hyponatremia, particularly in the absence of clear indicators of hypovolemia, such as orthostatic hypotension. Measurement of urine sodium and response to saline infusion may help to make a precise diagnosis (table 1) [18]. Low $\left[\mathrm{Na}^{+}\right]$in the urine suggests decreased volume; in contrast, SIADH usually results in an increased urine $\left[\mathrm{Na}^{+}\right]$. It is important to differentiate mild or early-onset hypovolemia from euvolemic hyponatremia. For example, hyponatremia occurring after neurosurgery may be caused by SIADH or cerebral 
salt wasting syndrome, both of which have a similar clinical presentation. An accurate diagnosis of the type of hyponatremia that occurs in patients who have undergone neurosurgery is critical because the treatment of each condition differs substantially, and the wrong approach can be potentially dangerous [22].

\section{Rate of Onset}

The symptoms of hyponatremia vary and are dependent on the rate of onset. Acute hyponatremia (onset $<48$ h) can result in coma, irreversible neurologic damage, respiratory arrest, brainstem herniation, and death [23]. Symptoms are more severe in acute hyponatremia because the brain cannot adapt rapidly to the change in serum $\left[\mathrm{Na}^{+}\right]$. Chronic hyponatremia (onset $>48 \mathrm{~h}$ ) produces more subtle symptoms, including lethargy, nausea, headache, and disorientation. In this case, the brain can compensate for falling serum $\left[\mathrm{Na}^{+}\right]$through the excretion of organic solutes that promote water loss and ameliorate brain swelling. This adaptation can minimize the risk of symptoms during chronic hyponatremia, but it may also lead to osmotic demyelination in association with rapid sodium correction [23].

\section{Therapeutic Approaches to Hyponatremia}

There is currently little consensus on the treatment of hyponatremia, and evidence-based guidelines are lacking. Fluid restriction is recommended as first-line therapy for the treatment of euvolemic hyponatremia, but its efficacy is unproven. This strategy is frequently impractical, particularly when restriction to less than 1 liter/day is required, and it causes inconvenience and discomfort to patients $[20,24]$. Demeclocycline has been recommended as second-line therapy, but it produces poor results and troublesome adverse events, including azotemia, photosensitivity, and nausea. It is also contraindicated in cirrhosis or renal failure [13, 25].

It is generally agreed that active treatment of symptomatic hyponatremia is necessary regardless of the disorder's etiology or rate of onset. After the underlying cause, if known, is eliminated, sodium replacement is effective in patients with symptomatic hyponatremia. In these patients, serum $\left[\mathrm{Na}^{+}\right]$must be monitored closely. In patients with acute symptomatic hyponatremia, hypertonic saline (3\%) should be administered at a rate of $1-$ $2 \mathrm{ml} / \mathrm{kg}$ per $\mathrm{h}$. In cases of volume overload, a loop diuretic should be administered. In patients with symptomatic chronic hyponatremia, the overall serum $\left[\mathrm{Na}^{+}\right]$should not be increased by more than $12 \mathrm{mEq} / \mathrm{l}$ over the first $24 \mathrm{~h}$, because rapid correction can produce osmotic demyelination and significant permanent neurologic deficits [13].

In patients with chronic hyponatremia, the brain adapts by depleting osmolites to avoid swelling. As a result, hyponatremia with slow onset may be relatively asymptomatic, even if severe. In such patients, overly rapid correction of sodium can produce central pontine myelinosis. The neurologic symptoms of pontine myelinolysis usually do not appear until several days after sodium administration and are irreversible [26]. Since current treatment strategies do not produce a predictable response, frequent monitoring is necessary to reduce the associated risks.

\section{AVP Receptors}

There are three distinct receptor subtypes that bind AVP and confer biologic activity at the target organ: the $\mathrm{V}_{2}$ receptors, which are found primarily in the kidney, the $\mathrm{V}_{1 \mathrm{~A}}$ receptors, which are expressed in vascular smooth muscle cells and in the heart, and the $\mathrm{V}_{3}$ receptors, which are found primarily in the anterior pituitary $[27,28]$. Less is known about the specific mechanisms of signal transduction pathways involving $\mathrm{V}_{3}$, which has a profile distinct from that of $\mathrm{V}_{1 \mathrm{~A}}$ and $\mathrm{V}_{2}$.

The physiologic action of AVP on water balance results from its binding to the $V_{2}$ renal receptor. The $V_{2}$ receptor is a G-protein-coupled receptor found on the basolateral membrane of the collecting duct. When bound to ligand, $\mathrm{V}_{2}$ acts through the $\mathrm{G} \alpha_{\mathrm{s}}$ stimulatory protein to increase adenyl cyclase activity to form cyclic adenosine monophosphate, which then activates protein kinase A. As a result, aquaporin- 2 is phosphorylated by protein kinase $A$ and mobilized to the luminal membrane, where it transports water from the collecting duct, thus increasing water reabsorption $[11,29]$. In normal physiologic states, renal escape from the antidiuretic effect of AVP occurs through the downregulation of aquaporin-2 and $V_{2}$ receptor binding in the kidney [30]. During pregnancy, SIADH, CHF, and cirrhosis, this escape mechanism is diminished and aquaporin-2 is chronically upregulated, increasing water retention proportionally with AVP secretion [31-33].

\section{AVP Receptor Antagonism}

Early pharmacologic efforts to block AVP at the receptor were focused on modifications of endogenous ligands to produce peptide antagonists $[34,35]$. The unfavorable pharmacokinetic and pharmacodynamic properties of 
these peptides precluded further clinical development $[28,36]$. The discovery of nonpeptide AVP antagonists through random screening has led to the synthesis of agents with potent antagonist properties against AVP receptors. These agents confirmed the role of AVP in the pathogenesis of hyponatremia and demonstrated the pharmacologic consequences of modifying AVP binding with the $\mathrm{V}_{2}$ receptor [37]. The development of AVP receptor antagonists has opened new avenues for a pharmacotherapy that addresses the underlying cause of hyponatremia directly.

\section{$V_{2}$ Receptor Antagonists}

A novel class of nonpeptide agents that demonstrate antagonism against the AVP $\mathrm{V}_{2}$ receptor have been developed recently. AVP receptor antagonism has been demonstrated to stimulate free water excretion without sodium loss [38]. In animal models, AVP receptor antagonists produced significant aquaretic effects without compensatory activation of the renin-aldosterone-angiotensin system, an undesirable adverse effect of diuretics $[39,40]$. Accordingly, specific AVP blockade has been shown to be beneficial in animal models of SIADH, CHF, and cirrhosis [39, 41-44]. The efficacy and tolerability of the $V_{2}$ receptor antagonists lixivaptan, tolvaptan, and OPC-31260 have been evaluated in clinical trials.

In a phase 2 study, 60 patients with dilutional hyponatremia (serum $\left[\mathrm{Na}^{+}\right]$between 115 and $132 \mathrm{mEq} / \mathrm{l}$ ) secondary to cirrhosis were randomly assigned to receive placebo $(\mathrm{n}=20)$, lixivaptan $100 \mathrm{mg} /$ day $(\mathrm{n}=22)$, or lixivap$\tan 200 \mathrm{mg} /$ day $(\mathrm{n}=18)$ for a maximum of 7 days [45]. Both lixivaptan 100 and $200 \mathrm{mg} /$ day produced significantly greater increases in FWC $[0.3 \pm 0.3 \mathrm{ml} / \mathrm{min}(\mathrm{p}<$ $0.01)$ and $1.2 \pm 0.4 \mathrm{ml} / \mathrm{min}(\mathrm{p}<0.001)$, respectively] than did placebo. Lixivaptan $200 \mathrm{mg} /$ day was associated with increased sodium excretion (from $24 \pm 8 \mathrm{mEq} / 12 \mathrm{~h}$ on day 1 to $34 \pm 17 \mathrm{mEq} / 12 \mathrm{~h}$ on the final day of treatment). Lixivaptan also increased serum $\left[\mathrm{Na}^{+}\right]$in accordance with the dosage given, whereas placebo did not. In patients given lixivaptan $100 \mathrm{mg} /$ day, the mean \pm SE serum $\left[\mathrm{Na}^{+}\right]$increased from $128.3 \pm 4.1$ to $130.4 \pm 6.5 \mathrm{mEq} / \mathrm{l}$ $(\mathrm{p}<0.053)$, and in those given lixivaptan $200 \mathrm{mg} /$ day, the serum $\left[\mathrm{Na}^{+}\right]$increased from $126.4 \pm 4.4$ to $132.3 \pm$ $6.9 \mathrm{mEq} / \mathrm{l}(\mathrm{p}<0.001)$. Lixivaptan $200 \mathrm{mg} /$ day was associated with increased thirst [45].

In another phase 2 trial, 44 patients with hyponatremia (serum $\left[\mathrm{Na}^{+}\right]<130 \mathrm{mEq} / \mathrm{l} ; 33$ patients with cirrhosis, 6 with CHF, and 5 with SIADH) were randomly assigned to receive placebo or daily doses of lixivaptan 25,125 or $250 \mathrm{mg}$ for 7 days [46]. Lixivaptan therapy produced sig- nificantly greater dose-related increases in FWC ( $\mathrm{p}<$ $0.05)$ and serum $\left[\mathrm{Na}^{+}\right](\mathrm{p}<0.05)$ than did placebo, without significant changes in orthostatic blood pressure. Urinary sodium excretion did not increase with lixivaptan therapy. Lixivaptan was generally well-tolerated, but higher doses were associated with increased thirst and excessive diuresis [46].

The role of tolvaptan in patients with CHF has been evaluated in two large-scale studies [47, 48]. The first study, 254 patients with CHF [New York Heart Association (NYHA) class I-III] were randomly assigned to 25 days of treatment with placebo or tolvaptan 30,45 or $60 \mathrm{mg} /$ day [47]. The primary efficacy variable was the mean decrease from baseline in body weight. All doses of tolvaptan produced significant weight reduction on the first day of treatment ( $p<0.001$ vs. placebo), but no further reductions were observed during the remainder of the study period. Total urine volume, which was collected only during the first day of treatment, was significantly greater in all three tolvaptan treatment groups $(30 \mathrm{mg} /$ day: 3,909 $\mathrm{ml} ; 45 \mathrm{mg} /$ day: 4,232 ml; $60 \mathrm{mg} /$ day: 4,597 ml) than in the placebo group $(2,328 \mathrm{ml} ; \mathrm{p}<0.05)$. A subset of 70 patients $(28 \%)$ had hyponatremia (serum $\left[\mathrm{Na}^{+}\right]$ $<136 \mathrm{mEq} / \mathrm{l}$ ) at baseline. At day 1 of treatment, $80 \%$ of patients given tolvaptan demonstrated normalization of serum $\left[\mathrm{Na}^{+}\right]$, compared with $40 \%$ of patients given placebo $(\mathrm{p}<0.05)$. Normalization of serum $\left[\mathrm{Na}^{+}\right]$was maintained throughout the study period in $82 \%$ of patients given tolvaptan and $40 \%$ of those given placebo $(\mathrm{p}<0.05)$ [47].

The second study included 319 hospitalized patients with CHF (NYHA class III-IV) and left ventricular ejection fraction less than $40 \%$ [48]. Patients were randomly assigned to receive placebo or tolvaptan (30,60 or $90 \mathrm{mg} /$ day) for 60 days (up to 10 days of inpatient treatment and then 7 weeks of outpatient treatment). The coprimary efficacy measures included the change in body weight at $24 \mathrm{~h}$ after administration of the first dose of study drug (during inpatient treatment) and worsening of heart failure 60 days after randomization (outpatient treatment). Patients given tolvaptan experienced significantly greater weight loss (median reduction, $1.8-2.1 \mathrm{~kg}$ ) than those who received placebo $(0.6 \mathrm{~kg} ; \mathrm{p}=0.002)$. Urine volume on day 1 was significantly higher in patients who received tolvaptan than in patients who received placebo and remained higher throughout the hospitalization period (fig. 1). The rate of worsening heart failure did not differ between the tolvaptan and placebo groups (26.7 vs. $27.5 \%$; $\mathrm{p}=0.88$ ). Baseline evaluations indicated that a subset of 68 patients (21.3\%) had hyponatremia (serum $\left[\mathrm{Na}^{+}\right]<136 \mathrm{mEq} / \mathrm{l}$ ). Af- 


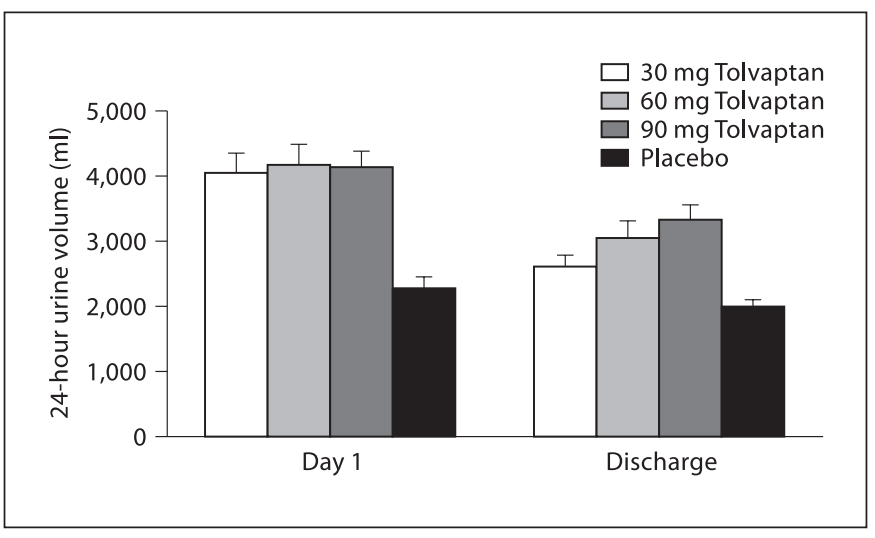

Fig. 1. Mean 24-hour urine volume ( \pm SE) at day 1 and at hospital discharge in patients given tolvaptan or placebo for the treatment of hyponatremia [adapted from 48]. $\mathrm{p}<0.001$ for all comparisons of tolvaptan groups vs. placebo, except for $30 \mathrm{mg}$ tolvaptan vs. placebo, for which $\mathrm{p}=0.02$ for both day 1 and discharge.

ter treatment with tolvaptan, these patients had a rapid and sustained increase in serum $\left[\mathrm{Na}^{+}\right][48]$.

The efficacy of OPC-31260, the compound from which tolvaptan was derived, was evaluated in 11 patients with hyponatremia (serum $\left[\mathrm{Na}^{+}\right]<135 \mathrm{mEq} / \mathrm{l}$ ) secondary to SIADH [49]. Those who received a single intravenous 0.25 or $0.5 \mathrm{mg} / \mathrm{kg}$ dose of OPC-31260 demonstrated both a urine volume 2.1 and 1.9 times, respectively, greater than that in control patients and a lower urine osmolality $(<225 \mathrm{mosm} / \mathrm{kg})$. The $0.5-\mathrm{mg} / \mathrm{kg}$ dose of OPC-31260 significantly increased serum $\left[\mathrm{Na}^{+}\right]$by about $3 \mathrm{mEq} / \mathrm{l}$ at $3 \mathrm{~h}$ after administration $\left(\mathrm{p}<0.01\right.$ vs. serum $\left[\mathrm{Na}^{+}\right]$at baseline) [49]. In a study of 8 patients with cirrhosis who had ascites or peripheral edema (serum $\left[\mathrm{Na}^{+}\right]$was in the normal range), a single $30-\mathrm{mg}$ oral dose of OPC-31260 significantly $(\mathrm{p}<0.01)$ increased the urinary excretion rate at $0-2 \mathrm{~h}$ after administration and significantly $(\mathrm{p}<0.01)$ lowered urine osmolality at $2-4 \mathrm{~h}$ [50]. FWC was also significantly $(\mathrm{p}<0.05)$ increased between 0 and $4 \mathrm{~h}$ after administration. OPC-31260, however, is no longer in clinical development.

\section{$V_{1 A} / V_{2}$ Receptor Antagonist}

Conivaptan, a $\mathrm{V}_{1 \mathrm{~A}}$ and $\mathrm{V}_{2}$ receptor antagonist, is the first agent in this class to be approved for the treatment of euvolemic hyponatremia in hospitalized patients. In preclinical studies, the aquaretic effect of conivaptan was similar to or greater than that of a loop diuretic, but without the accompanying loss of electrolytes $[51,52]$.

A phase 3 randomized, double-blind, multicenter, placebo-controlled, parallel-group trial compared the effi-

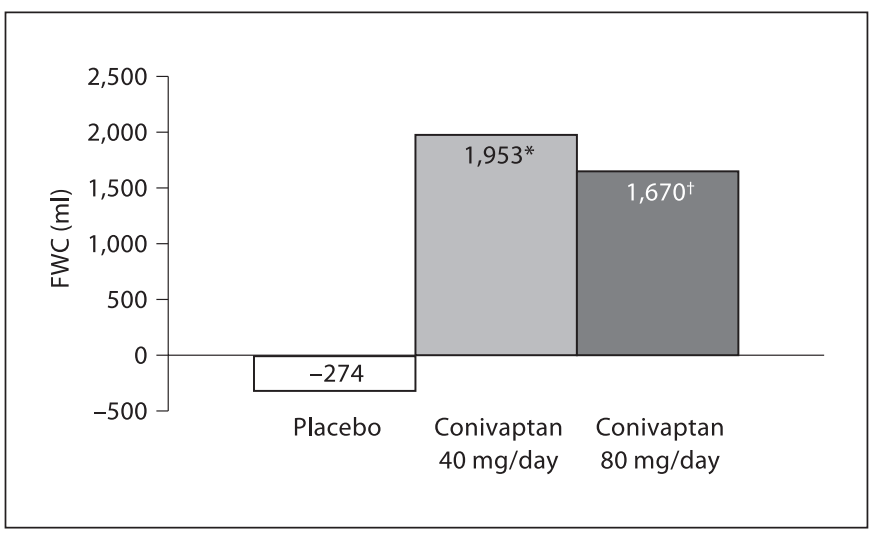

Fig. 2. Effect of conivaptan on least squares mean change from baseline in FWC at day 1 in patients with euvolemic or hypervolemic hyponatremia [54]. ${ }^{*} \mathrm{p}=0.0004 ;{ }^{\dagger} \mathrm{p}=0.0007$.

cacy and tolerability of intravenous conivaptan (a 20-mg loading dose followed by continuous infusion of 40 or $80 \mathrm{mg} /$ day for 4 days) with that of placebo in 85 patients with euvolemic or hypervolemic hyponatremia (serum $\left[\mathrm{Na}^{+}\right] 115$ to $<130 \mathrm{mEq} / \mathrm{l}$ ) [53]. Both conivaptan doses produced a significant increase in FWC at day 1 (fig. 2) [54]. Normalization of serum $\left[\mathrm{Na}^{+}\right](\geq 135 \mathrm{mEq} / \mathrm{l})$ or a $\geq 6$ - $\mathrm{mEq} / \mathrm{l}$ increase from baseline in serum $\left[\mathrm{Na}^{+}\right]$occurred in significantly more patients given either conivap$\tan 40 \mathrm{mg}(69 \%)$ or $80 \mathrm{mg} /$ day $(88 \%)$ than in those given placebo $(21 \%$; $<<0.01$ and $\mathrm{p}<0.001$, respectively). The median time for an increase in serum $\left[\mathrm{Na}^{+}\right] \geq 4 \mathrm{mEq} / \mathrm{l}$ from baseline was approximately $24 \mathrm{~h}$ for both treatment groups ( $\mathrm{p}<0.001)$ (not estimable for the placebo group).

The safety and efficacy of oral conivaptan have also been evaluated in two additional phase 3 clinical trials that included 83 and 74 patients, respectively, with euvolemic or hypervolemic hyponatremia who were given conivaptan 40 or $80 \mathrm{mg} /$ day or placebo for 5 days $[55,56]$. Oral conivaptan produced significant increases in serum $\left[\mathrm{Na}^{+}\right](\mathrm{p}<0.05)$ and effective water clearance within the first day of treatment and was well tolerated in patients with hyponatremia. The incidences of drug-related adverse events were comparable among treatment groups. In vivo and in vitro studies indicate that conivaptan is a substrate and potent inhibitor of cytochrome P450 3A4, the liver and small intestine isoenzyme responsible for drug metabolism. Based on these findings, only the intravenous formulation of conivaptan is available for the treatment of euvolemic hyponatremia. 


\section{Conclusions}

Hyponatremia, a serious electrolyte disorder, occurs most frequently as a complication in the elderly and in patients with SIADH, CHF, or cancer. Until now, the available therapeutic options for treating the various forms of hyponatremia have been limited. AVP receptor antagonism is a novel therapeutic approach involving a new class of pharmacologic agents. The results of clinical studies suggest that the AVP receptor antagonists will promote safe aquaresis through the electrolyte-sparing excretion of free water and correction of serum $\left[\mathrm{Na}^{+}\right]$in patients with euvolemic or hypervolemic hyponatremia.

\section{References}

$\checkmark 1$ Kennedy PG, Mitchell DM, Hoffbrand BI: Severe hyponatraemia in hospital inpatients. Br Med J 1978;2:1251-1253.

-2 Anderson RJ, Chung HM, Kluge R, Schrier RW: Hyponatremia: a prospective analysis of its epidemiology and the pathogenetic role of vasopressin. Ann Intern Med 1985;102:164168.

3 Gill G, Leese G: Hyponatraemia: biochemical and clinical perspectives. Postgrad Med J 1998;74:516-523.

4 Tierney WM, Martin DK, Greenlee MC, Zerbe RL, McDonald CJ: The prognosis of hyponatremia at hospital admission. J Gen Intern Med 1986;1:380-385.

5 Hawkins RC: Age and gender as risk factors for hyponatremia and hypernatremia. Clin Chim Acta 2003;337:169-172.

-6 Baran D, Hutchinson TA: The outcome of hyponatremia in a general hospital population. Clin Nephrol 1984;22:72-76.

7 Terzian C, Frye EB, Piotrowski ZH: Admission hyponatremia in the elderly: factors influencing prognosis. J Gen Intern Med 1994; 9:89-91.

8 Fraser CL, Arieff AI: Epidemiology, pathophysiology, and management of hyponatremic encephalopathy. Am J Med 1997;102: $67-77$.

-9 Verbalis JG: Disorders of body water homeostasis. Best Pract Res Clin Endocrinol Metab 2003;17:471-503.

$\longrightarrow 10$ Arnauld E, Vincent JD, Dreifuss JJ: Firing patterns of hypothalamic supraoptic neurons during water deprivation in monkeys. Science 1974; 185:535-537.

-11 Ferguson JW, Therapondos G, Newby DE, Hayes PC: Therapeutic role of vasopressin receptor antagonism in patients with liver cirrhosis. Clin Sci (Lond) 2003;105:1-8.

$\checkmark 12$ Andreoli TE: Water: normal balance, hyponatremia, and hypernatremia. Ren Fail 2000; 22:711-735.

$\checkmark 13$ Fried LF, Palevsky PM: Hyponatremia and hypernatremia. Med Clin North Am 1997; 81:585-609.

14 Robinson AG: Disorders of antidiuretic hormone secretion. Clin Endocrinol Metab 1985; 14:55-88.

15 Luckey AE, Parsa CJ: Fluid and electrolytes in the aged. Arch Surg 2003;138:1055-1060.
16 Davison JM, Shiells EA, Philips PR, Lindheimer MD: Serial evaluation of vasopressin release and thirst in human pregnancy. Role of human chorionic gonadotrophin in the osmoregulatory changes of gestation. J Clin Invest 1988;81:798-806.

17 Freda BJ, Davidson MB, Hall PM: Evaluation of hyponatremia: a little physiology goes a long way. Cleve Clin J Med 2004;71:639650.

18 Yeates KE, Singer M, Morton AR: Salt and water: a simple approach to hyponatremia. CMAJ 2004;170:365-369.

19 Adrogué HJ, Madias NE: Hyponatremia. N Engl J Med 2000;342:1581-1589.

20 Palmer BF: Hyponatremia in patients with central nervous system disease: SIADH versus CSW. Trends Endocrinol Metab 2003;14: 182-187.

21 Bartter FC, Schwartz WB: The syndrome of inappropriate secretion of antidiuretic hormone. Am J Med 1967;42:790-806.

22 Betjes MG: Hyponatremia in acute brain disease: the cerebral salt wasting syndrome. Eur J Intern Med 2002;13:9-14.

23 Soupart A, Decaux G: Therapeutic recommendations for management of severe hyponatremia: current concepts on pathogenesis and prevention of neurologic complications. Clin Nephrol 1996;46:149-169.

- 24 Ginés P, Berl T, Bernardi M, Bichet DG, Hamon G, Jimenez W, Liard JF, Martin PY, Schrier RW: Hyponatremia in cirrhosis: from pathogenesis to treatment. Hepatology 1998;28:851-864.

-25 Miller PD, Linas SL, Schrier RW: Plasma demeclocycline levels and nephrotoxicity. Correlation in hyponatremic cirrhotic patients. JAMA 1980;243:2513-2515.

26 Janicic N, Verbalis JG: Evaluation and management of hypo-osmolality in hospitalized patients. Endocrinol Metab Clin North Am 2003;32:459-481.

-27 Kaufmann JE, Oksche A, Wollheim CB, Gunther G, Rosenthal W, Vischer UM: Vasopressin-induced von Willebrand factor secretion from endothelial cells involves V2 receptors and cAMP. J Clin Invest 2000;106: 107-116.
28 Lee CR, Watkins ML, Patterson JH, Gattis W, O'Connor CM, Gheorghiade M, Adams KF Jr: Vasopressin: a new target for the treatment of heart failure. Am Heart J 2003;146: 9-18.

29 Ishikawa SE, Schrier RW: Pathophysiological roles of arginine vasopressin and aquaporin-2 in impaired water excretion. Clin Endocrinol (Oxf) 2003;58:1-17.

30 Ecelbarger CA, Chou CL, Lee AJ, DiGiovanni SR, Verbalis JG, Knepper MA: Escape from vasopressin-induced antidiuresis: role of vasopressin resistance of the collecting duct. Am J Physiol 1998;274:F1161-F1166.

- 31 Szatalowicz VL, Arnold PE, Chaimovitz C, Bichet D, Berl T, Schrier RW: Radioimmunoassay of plasma arginine vasopressin in hyponatremic patients with congestive heart failure. N Engl J Med 1981;305:263-266.

32 Camps J, Sola J, Arroyo V, Perez-Ayuso RM, Gaya J, Rivera F, Rodes J: Temporal relationship between the impairment of free water excretion and antidiuretic hormone hypersecretion in rats with experimental cirrhosis. Gastroenterology 1987;93:498-505.

- 33 Nielsen S, Kwon TH, Christensen BM, Promeneur D, Frokiaer J, Marples D: Physiology and pathophysiology of renal aquaporins. J Am Soc Nephrol 1999;10:647-663.

- 34 Thibonnier M, Coles P, Thibonnier A, Shoham M: The basic and clinical pharmacology of nonpeptide vasopressin receptor antagonists. Annu Rev Pharmacol Toxicol 2001;41: 175-202.

35 Manning M, Sawyer WH: Discovery, development, and some uses of vasopressin and oxytocin antagonists. J Lab Clin Med 1989; 114:617-632.

36 Palm C, Reimann D, Gross P: The role of V2 vasopressin antagonists in hyponatremia. Cardiovasc Res 2001;51:403-408.

- 37 Palm C, Gross P: V2-vasopressin receptor antagonists - mechanism of effect and clinical implications in hyponatraemia. Nephrol Dial Transplant 1999;14:2559-2562.

38 Ohnishi A, Orita Y, Okahara R, Fujihara H, Inoue T, Yamamura Y, Yabuuchi Y, Tanaka T: Potent aquaretic agent. A novel nonpeptide selective vasopressin 2 antagonist (OPC31260 ) in men. J Clin Invest 1993;92:26532659. 
39 Naitoh M, Risvanis J, Balding LC, Johnston CI, Burrell LM: Neurohormonal antagonism in heart failure; beneficial effects of vasopressin $\mathrm{V}(1 \mathrm{a})$ and $\mathrm{V}(2)$ receptor blockade and ACE inhibition. Cardiovasc Res 2002;54:5157.

40 Burrell LM, Phillips PA, Risvanis J, Chan RK, Aldred KL, Johnston CI: Long-term effects of nonpeptide vasopressin V2 antagonist OPC-31260 in heart failure in the rat. Am J Physiol 1998;275:H176-H182.

41 Naitoh M, Suzuki H, Murakami M, Matsumoto A, Arakawa K, Ichihara A, Nakamoto H, Oka K, Yamamura Y, Saruta T: Effects of oral AVP receptor antagonists OPC-21268 and OPC-31260 on congestive heart failure in conscious dogs. Am J Physiol 1994;267: H2245-H2254.

42 Nishikimi T, Kawano Y, Saito Y, Matsuoka $\mathrm{H}$ : Effect of long-term treatment with selective vasopressin V1 and V2 receptor antagonist on the development of heart failure in rats. J Cardiovasc Pharmacol 1996;27:275282.

43 Fujisawa G, Ishikawa S, Tsuboi Y, Okada K, Saito T: Therapeutic efficacy of non-peptide ADH antagonist OPC-31260 in SIADH rats. Kidney Int 1993;44:19-23.

-44 Tsuboi Y, Ishikawa S, Fujisawa G, Okada K, Saito T: Therapeutic efficacy of the non-peptide AVP antagonist OPC-31260 in cirrhotic rats. Kidney Int 1994;46:237-244.

-45 Gerbes AL, Gulberg V, Gines P, Decaux G, Gross P, Gandjini H, Djian J; VPA Study Group: Therapy of hyponatremia in cirrhosis with a vasopressin receptor antagonist: a randomized double-blind multicenter trial. Gastroenterology 2003;124:933-939.
46 Wong F, Blei AT, Blendis LM, Thuluvath PJ: A vasopressin receptor antagonist (VPA985) improves serum sodium concentration in patients with hyponatremia: a multicenter, randomized, placebo-controlled trial. Hepatology 2003;37:182-191.

47 Gheorghiade M, Niazi I, Ouyang J, Czerwiec F, Kambayashi J, Zampino M, Orlandi C; Tolvaptan Investigators: Vasopressin V2-receptor blockade with tolvaptan in patients with chronic heart failure: results from a double-blind, randomized trial. Circulation 2003;107:2690-2696.

48 Gheorghiade M, Gattis WA, O'Connor CM, Adams KF Jr, Elkayam U, Barbagelata A, Ghali JK, Benza RL, McGrew FA, Klapholz M, Ouyang J, Orlandi C; Acute and Chronic Therapeutic Impact of a Vasopressin Antagonist in Congestive Heart Failure (ACTIV in $\mathrm{CHF}$ ) Investigators: Effects of tolvaptan, a vasopressin antagonist, in patients hospitalized with worsening heart failure: a randomized controlled trial. JAMA 2004;291:19631971.

49 Saito T, Ishikawa S, Abe K, Kamoi K, Yamada K, Shimizu K, Saruta T, Yoshida S: Acute aquaresis by the nonpeptide arginine vasopressin (AVP) antagonist OPC-31260 improves hyponatremia in patients with syndrome of inappropriate secretion of antidiuretic hormone (SIADH). J Clin Endocrinol Metab 1997;82:1054-1057.

50 Inoue $\mathrm{T}$, Ohnishi A, Matsuo A, Kawai B, Kunihiro N, Tada Y, Koizumi F, Chau T, Okada K, Yamamura Y, Tanaka T: Therapeutic and diagnostic potential of a vasopressin2 antagonist for impaired water handling in cirrhosis. Clin Pharmacol Ther 1998;63: 561-570.
51 Risvanis J, Naitoh M, Johnston CI, Burrell LM: In vivo and in vitro characterisation of a nonpeptide vasopressin $\mathrm{V}(1 \mathrm{~A})$ and $\mathrm{V}(2)$ receptor antagonist (YM087) in the rat. Eur J Pharmacol 1999;381:23-30.

52 Tomura Y, Tahara A, Tsukada J, Yatsu T, Uchida W, Iizumi Y, Honda K: Pharmacological profile of orally administered YM087, a vasopressin antagonist, in conscious rats. Clin Exp Pharmacol Physiol 1999;26:399403.

53 Verbalis JG, Bisaha JG, Smith N: Novel vasopressin V1A and V2 antagonist conivaptan increases serum sodium concentration and effective water clearance in hyponatremia. J Am Soc Nephrol 2004;15:356A.

54 Verbalis JG, Ghali JK, Gross P, Long WA, Smith N: Conivaptan, a novel arginine vasopressin antagonist, produced aquaresis and increased serum sodium concentration in patients with euvolemic and hypervolemic hyponatremia. Pharmacotherapy 2005;25: 1454.

55 Ghali JK, Bisaha JG, Smith N: Efficacy of the vasopressin V1A/V2 antagonist conivaptan in patients with euvolemic or hypervolemic hyponatremia. J Am Soc Nephrol 2004;15: 355A.

56 Gross P, Bisaha JG, Smith N: Conivaptan, a novel V1A and V2 antagonist, increased serum sodium and effective water clearance in patients with euvolemic or hypervolemic hyponatremia. J Am Soc Nephrol 2004;15: $355 \mathrm{~A}$. 